\title{
Experimental Studies of Sustainable Cement Concrete Pavement
}

\author{
Shibashish P. Mukherjee ${ }^{1}$, Dr Gaurang Vesmawala ${ }^{2}$ \\ ${ }^{1}$ Project Manager M/S Mass Infrastructure Private Limited Vadodara, India \\ ${ }^{2}$ Assistant Professor in Applied Mechanic Sardar Vallabhai Institute of Technology, Surat, India
}

\begin{abstract}
The difference in the construction cost of concrete and bituminous roads has narrowed down considerably on account of sudden rise of cost of bitumen. Now a day's cement concrete Roads are more preferred than bituminous roads in urban cities in India. Concrete roads are potential users of Cement. The behavior of concrete, whether fresh or hardened, depends basically on the behavior of its components and the relationship between them, therefore, obtaining a concrete with certain properties depends fundamentally on the concrete mix design.
\end{abstract}

Keywords: Fly ash, HVFAC, Sustainability, LCA, PQC, DLC, Mix Design

\section{Introduction}

A large amount of theoretical and experimental research programs were carried out by many universities and research institution in various countries. As a result, a great deal of useful information has been disseminated, and fruitful results have been put into practice. Yet, there is a need for developing a comprehensive understanding about the detailed contribution of Aggregates sizes, shape, gradation, towards minimizing the Cement Content. Different Codial Provisions for Concrete Mix Design, use of chemical \& mineral admixture, for Pavement concrete. As per guidelines laid by new government all new Highway Projects supported by NHAI of India will use Cement Concrete.

The entire $28 \mathrm{KM}$ stretch for Satara-Kolhapur section of NH4 has been constructed with 40\%age Flyash as replacement of Cementitious material for PQC \& DLC, duration May 2002 to February 2005. As per IRC: SP: 84-2014 provides guidelines for design \& construction the proposed alternative conforms to any one of the international standards, code of practice, specifications, guidelines etc.

a) IRC revised codes or new codes or amendments to existing codes

b) American Association of State Highway and Transportation Officials (AASHTO)

c) American Society for Testing of Materials (ASTM)

d) Euro Codes

e) National Standards of any of the following countries: United States of America (USA), Canada, United Kingdom (UK), France, Germany, Sweden, Denmark, Norway, Netherlands, Spain, Australia, New Zealand, Japan and South Africa.

\section{General}

Roads are the arteries and the veins of a nation. They not only foster the economic growth of a nation but unite and uniform the whole nation. Roads are essential ingredients for rapid growth of an economy and a vital input to economic development, trade and social integration, which rely on the conveyance of both people and goods. Both the urban and the rural markets benefits with two traffic and have the upward spiral effect on the life style of the nation. India is most recent examples of the effect of roads on the economic development of the country. With two decades of conscious efforts to built roads to connect the entire country, the face of the whole nation is changed. The overall effect is the creation of more and more opportunities with the construction of the roads and with it there is overall buoyancy in the country. [17, 20]

\section{Literature Review And Need Of The Study}

Due to growing interest in sustainable development engineers and architects are motivated more than ever before to choose materials that are more sustainable. Engineers and architects have choices of the material and products they use to design projects - when it comes to a building frame the choice is typically between concrete, steel and wood; for paving applications the choice is generally between concrete and asphalt. Material choice depends on several factors including first cost, life cycle cost and performance for a specific application. However this is not as straight forward as selecting an energy star rated appliance or a vehicle providing high gas mileage.

Life Cycle Assessment (LCA) seems to offer a solution. LCA considers materials over the course of their entire life cycle including material extraction, manufacturing, construction, operations, and finally reuse/recycling. LCA takes into account a full range of environmental impact indicators-including embodied 
energy, air and water pollution (including greenhouse gases), and potable water consumption, solid waste and recycled content. Recent focus on climate change and the impact of greenhouse gas emissions on our environment has caused many to focus on $\mathrm{CO}_{2}$ emissions as the most critical environmental impact indicator. Recent research at the Massachusetts Institute of Technology (MIT) explores advances key areas relevant to the field of pavement LCA: methodology, benchmarking and impact reduction.

Designing and proportioning of ingredients in a concrete mix requires sound technical skill which should further incorporate all possible variation in properties of the ingredients. Bureau of Indian standard in this direction released IS: 102621982 which was further revised in the year 2009. IRC: 44-1976 "Tentative Guidelines for Cement Concrete Mix Design for Pavement" was prepared by Cement Road Surfacing Committee. The Revision of IRC:44 1976 was taken up by the Rigid Pavement Committee (H-3) and the revised draft as prepared by document incorporating the comments of the HSS Committee was approved for printing in the year 2008. The objective of the study was to check whether the new guidelines ensure better and economical concrete mixes.

Here study was carried to prepare M40 Mix Design as per Indian Standards Old \& New Guidelines i.e. I.S:10262- 1982 \& I.S:10262-2009 and also with Indian Road Congress Old \& New Mix Design Guide lines i.e. IRC: 44-1976 \& I.R.C:44-2008, here study was done to ensure whether the new \& old guidelines of both Indian Standards \& Indian Road Congress will give better and economical concrete mixes. Previously no comparisons has been done between IRC old \& new code, whereas no study was carried out to check \& ensure better \& economical concrete mixes with Indian Standard \& Indian Road Congress Mix Design guidelines. In addition to this study effect of proper size and grading of aggregates to be used in concrete and prepare job mix formula. To Work out proper dosage\& brand of super plastizer to be used in the Design mix.

Many investigations are performed to evaluate the long-term performance of concrete pavements made high volumes fly ash (FA), the theory and construction practice with concrete mixtures containing more than $50 \%$ fly ash by mass of the cementitious material. There has been quite a few research studies carried out for the laboratory investigations of high performance concrete mix to study the suitability on basis of various laboratory tests. [21-23]. In the present study the Verification of engineering properties of M40 Concrete produced generally meant to be used for Rigid Pavement with significant less cement content. Parametric study of Engineering properties like Workability Test, Density of Concrete, Flexural strength, Equivalent Cube Strength has been carried out here.

An equally important goal at this point is to determine fairly M40 Concrete is prepared on Basis of IRC: 44-2008, Design Guide lines as provided in IRC: 15-2011 "Standard Specification and code of practice for construction of Concrete Roads" is followed Gradation of aggregates as provided in table: 3 of IRC: 15 is followed. After preparing the final Mix fiber dosage at the rate of $125 \mathrm{gm}$ per $50 \mathrm{~kg}$ of Cementious Material is used. A Trial Patch of @ $1.0 \mathrm{mt}$ X $3.0 \mathrm{mt}$ of $300 \mathrm{~mm}$ thickness done, its site evaluation of strength is done by cutting 3 nos of cores and working out is compressive strength. Thus, the research work is extended to obtain a sustainable Green M40 Pavement Quality Concrete to be used in Highway Construction.

\section{Research Objectives}

To accomplish the purpose of the study, the main objectives can be identified as follows and viewed as flowchart in Figure 1.

1. Experimental study of Old \& New code used for Concrete Mix Design, Further deciding the codal provision to be used to decide the Water to Cementitious ratio.

2. To decide the proper dosage of super plastizer to be used in the Design mix.

3. To find out the proper size and grading of aggregates to be used in concrete.

4. To carry out Mix Design for Flexural Strength and verify its equivalent Cube strength as per I.S 516-2004.

5. To minimizes the Cement Content in the Design Mix.

6. To further reduce the cement content in the mix by using Fly Ash as a replacement for Cement.

a) $25 \%$ age Cement replaced by fly ash

b) $40 \%$ age Cement replaced by fly ash

c) $55 \%$ age Cement replaced by fly ash

7. To prepare M40 Mix Design in accordance to codial provision of IRC-44 2008 \& follow Design Guidelines as per IRC1-15 2011. 


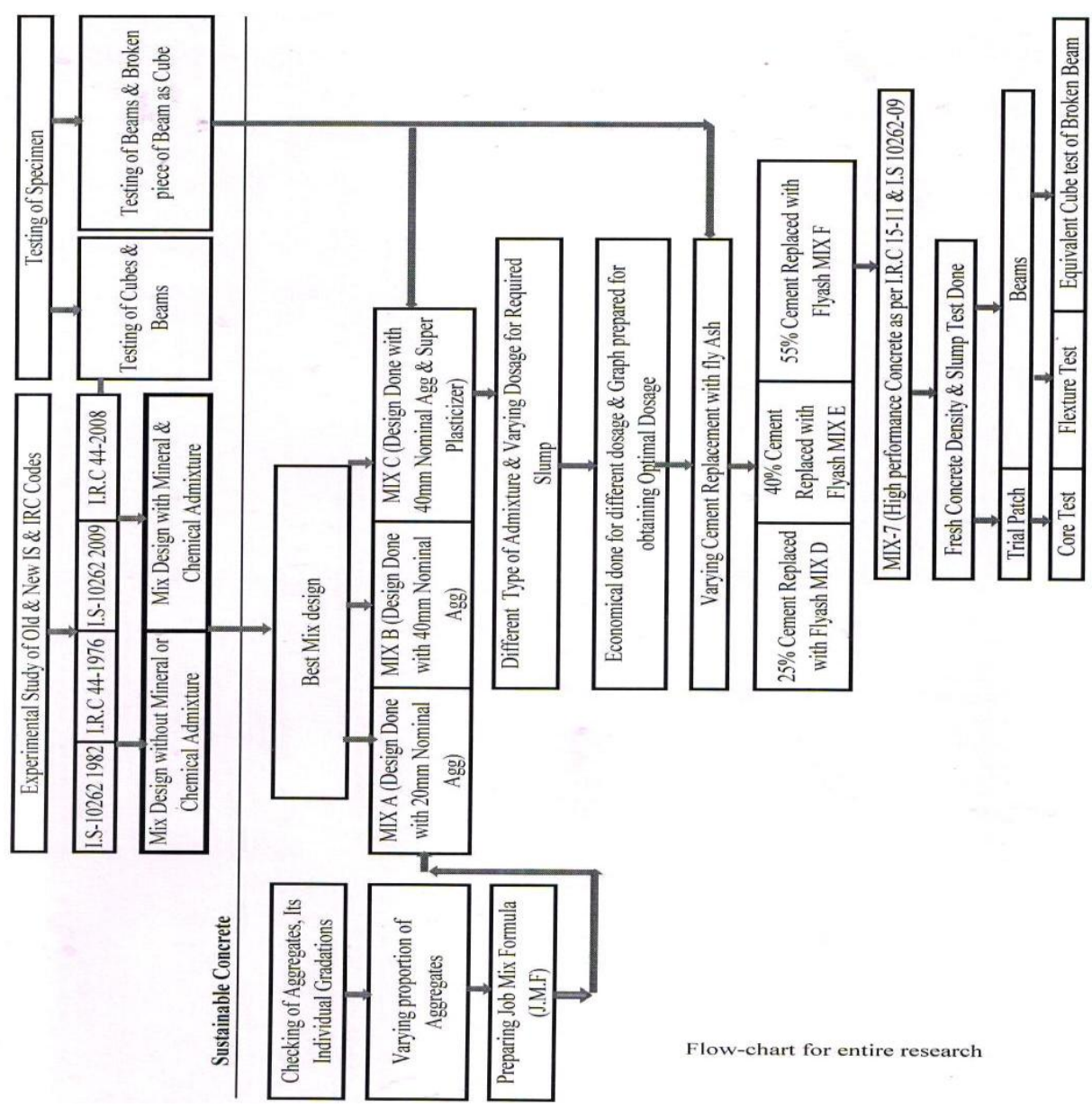

III. Experimental Study Of Old \& New Code Used For Concrete Mix Design Concrete Mix Design

Concrete mix design is defined as the appropriate selection and proportioning of constituents to produce a concrete with pre-defined characteristics in the fresh and hardened states. In general, concrete mixes are designed in order to achieve a defined workability, strength and durability. The mix design methods being used in different countries are mostly based on empirical relationships, charts and graphs developed from extensive experimental investigations. Most of them follow the same basic principles and only minor variations exist in different mix design methods in the process of selecting the mix proportions.

\subsection{Illustrative Examples}

Four illustrative examples two of each of M40 concrete mix proportion is given in Column $2 \& 3$. The Column 2 is an example of Mix proportion of M40 concrete, the mix is prepared on Design principle of IS 102621982 old edition. Column 3 represents proportion of M40 concrete based on Design Principle of IS 10262 2009 First revision. Both this concrete is to be used for Pavement Quality Concrete (PQC) in road work. Remaining Two illustrative example of concrete mix proportioning for conventional concrete pavement (PQC) is given in Column $4 \& 5$. The Column 4 is an example of Mix proportion of M40 grade of concrete, the mix is prepared on Design principle of IRC 441976 first revision. Column 5 represents proportion of M40 concrete based on Design Principle of IRC 442008 second revision.

Table 3.1 Ingredients of Concrete Raw Material as per Previous \& Revised I.S \& I.R.C Codes for Mix Design

\begin{tabular}{|c|c|c|c|c|}
\hline Ingredients & $\begin{array}{l}\text { Trial-1 with I.S } \\
10262-1982\end{array}$ & $\begin{array}{l}\text { Trial-2 with } \\
\text { IRC:44-1976 }\end{array}$ & $\begin{array}{lr}\text { Trial-3 } & \text { with } \\
\text { I.S } & 10262- \\
2009 & \\
\end{array}$ & $\begin{array}{l}\text { Trial-4 with } \\
\text { IRC:44-2008 }\end{array}$ \\
\hline Grade Of Concrete & M40 & M40 & M40 & M40 \\
\hline $\begin{array}{l}\text { Characteristics Compressive } \text { Strength in } \\
\mathrm{N} / \mathrm{mm}^{2}\end{array}$ & 49.24 & 47.06 & 48.25 & 48.25 \\
\hline Characteristics Tensile Strength in N/mm ${ }^{2}$ & 4.427 & 4.427 & 4.427 & 4.427 \\
\hline Cement & 428.57 & 406.98 & 330.00 & 347.37 \\
\hline Water & 165.00 & 175.00 & 132.00 & 132.00 \\
\hline
\end{tabular}




\begin{tabular}{|c|c|c|c|c|c|c|}
\hline \multirow{4}{*}{\multicolumn{2}{|c|}{ Fine Aggregate }} & Narmada & 430.19 & 313.67 & 270.32 & 254.90 \\
\hline & & Tapi & 430.19 & 313.67 & 270.32 & 254.90 \\
\hline & & $20 \mathrm{~mm}$ & 696.38 & 627.26 & 774.38 & 746.00 \\
\hline & & $10 \mathrm{~mm}$ & 696.38 & 627.26 & 774.38 & 746.00 \\
\hline \multicolumn{3}{|c|}{ Chemical Admixture } & Nil & Nil & 6.60 & 6.950 \\
\hline \multicolumn{3}{|c|}{ Water-Cement ratio } & 0.385 & 0.430 & 0.400 & 0.380 \\
\hline \multicolumn{3}{|c|}{ Date of Casting } & $27 / 05 / 2012$ & $2 / 6 / 2012$ & $13 / 06 / 2012$ & $18 / 06 / 2012$ \\
\hline \multicolumn{3}{|c|}{ Ingredients } & $\begin{array}{l}\text { Trial-1 with I.S } \\
\text { 10262-1982 }\end{array}$ & $\begin{array}{l}\text { Trial-2 with } \\
\text { IRC:44-1976 }\end{array}$ & $\begin{array}{lr}\text { Trial-3 } & \text { with } \\
\text { I.S } & 10262- \\
2009 & \end{array}$ & $\begin{array}{l}\text { Trial-4 with } \\
\text { IRC:44-2008 }\end{array}$ \\
\hline \multicolumn{3}{|c|}{$\begin{array}{l}\text { Observed slump in } \mathrm{mm} \text { after } 15 \text { minutes } \\
\text { from addition of water }\end{array}$} & 10 & 30 & 25 & 25 \\
\hline \multicolumn{3}{|c|}{ Concrete looks } & Harsh & Cohesive & Cohesive & Cohesive \\
\hline \multicolumn{3}{|c|}{ Density Of cube } & 2.635 & 2.588 & 2.654 & 2.654 \\
\hline \multirow[t]{5}{*}{ Results } & \multicolumn{2}{|c|}{ 3'Days Compressive Strength } & 28 & 27.852 & 26.815 & 29.926 \\
\hline & \multicolumn{2}{|c|}{ 7'Days Compressive Strength } & 35 & 28.552 & 28.145 & 30.963 \\
\hline & \multicolumn{2}{|c|}{$\begin{array}{ll}28 \text { 'Days } & \text { Compressive } \\
\text { Strength } & \\
\end{array}$} & 56.185 & 48.18 & 46.519 & 47.125 \\
\hline & \multicolumn{2}{|c|}{ 7'Days Flexural Strength } & 4.326 & 4.978 & 5.393 & 4.504 \\
\hline & \multicolumn{2}{|c|}{ 28'Flexural Strength } & 6.136 & 4.8 & 6.104 & 6.051 \\
\hline \multicolumn{3}{|c|}{ Aggregates to Cement Ratio } & 5.257 & 4.625 & 6.332 & 5.763 \\
\hline
\end{tabular}

\section{Discussion}

Here comparison of Ingredients obtained for Different Guidelines for Mix Design Codes of Previous \& Revised I.S \& I.R.C is tabulated its workability in terms of slump is worked out along with compressive strength of cubes. The Mix as per I.S 102621982 guidelines is Harsh comparative to other Mix obtained from other Mix Design Guidelines, its Compressive \& Flexural Strength is the most in all of the four Design. The Mix Obtained with new codes of I.S \& I.R.C guidelines is cohesive.

\section{Experimental Program}

The following test program was planned in order to evaluate the material proportions as required in the design of pavements and to investigate the structural strength (Flexural Strength) of high strength high performance concrete pavements using different proportion of fly ash as cement replacement.

\subsection{Experimental Investigation to prepare Mix A, Mix B}

Design of concrete mix of M-40 grade and evaluation of flexural strength, equivalent cube strength for determining its Compressive Strength.

\subsubsection{Materials}

Concrete mix of M40 has been developed .The characteristics of the various materials used in the present investigation i.e. cement, fly ash, coarse aggregate, fine aggregate, water \& super plasticizer are as follows

Cement: Ordinary Portland cement, Grade-53, confirming to IS: 12269-1967 was used throughout the investigation.

Water: Water used for mixing and curing should be free from injurious and deleterious materials. Throughout the investigation, potable tap water was used.

Coarse Aggregate: Locally available crushed stone coarse aggregate of maximum size $40 \mathrm{~mm}$ used along with $20 \mathrm{~mm} \& 10 \mathrm{~mm}$ confirming to IS: 383:1970 was used. The fineness modulus of coarse aggregate in the study is 6.7.

Fine Aggregate: Fine aggregate, locally available confirming to IS: 383-1970 is used. Two source of River sand one Tapi \& one Narmada is used. The proportion of both the sand has been decided on Job Mix Formula for All-in-Aggregate confirming to IS: $383-1970$. The fineness modulus in the study used is 2.89 .

Two different mixtures Mix A \& Mix B are developed for this Investigation work one by using Nominal aggregates of $20 \mathrm{~mm}$ and in Second mixture Nominal Size of aggregates considers is $40 \mathrm{~mm}$ instead of regular $20 \mathrm{~mm}$ size.

Individual gradation of Fine \& Coarse aggregates were done so as to established ideal proportion of aggregates so that value of all in aggregates comes in the centre of envelope. 

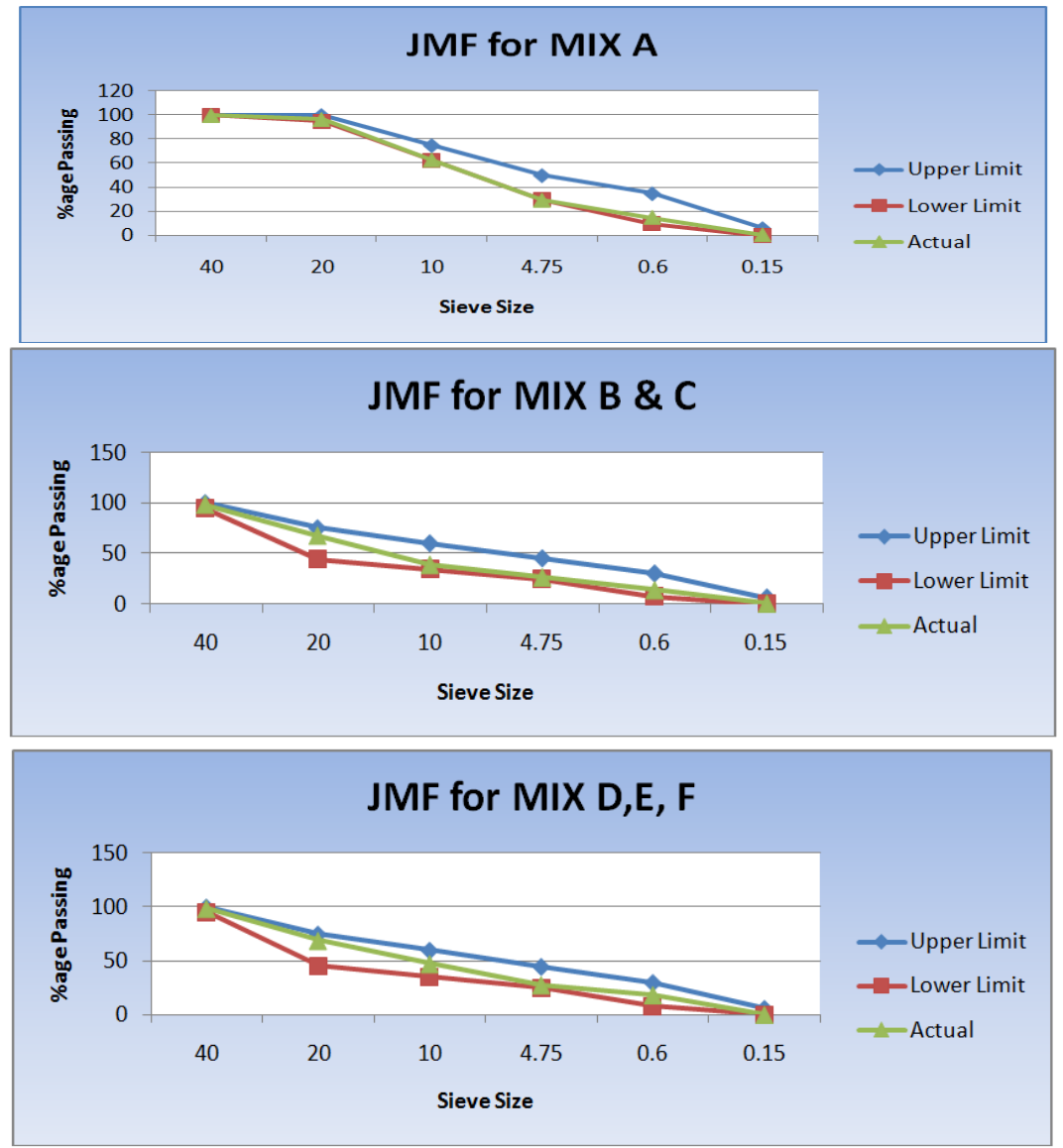

Table 4.1 Design of Mix Proportion for M40 for Designed flexural strength

\begin{tabular}{|c|c|c|c|}
\hline \multicolumn{2}{|l|}{ Ingredients in Kg } & Mix-A & Mix-B \\
\hline \multicolumn{2}{|l|}{ Cement } & 489.47 & 434.21 \\
\hline \multicolumn{4}{|l|}{ Fly Ash } \\
\hline \multicolumn{2}{|l|}{ Water } & 186.00 & 165.00 \\
\hline \multirow[t]{2}{*}{ Fine Aggregate } & Narmada & 235.94 & 243.31 \\
\hline & Tapi & 235.94 & 243.31 \\
\hline \multirow[t]{3}{*}{ Coarse Aggregate } & $40 \mathrm{~mm}$ & 0.00 & 569.67 \\
\hline & $20 \mathrm{~mm}$ & 552.41 & 569.67 \\
\hline & $10 \mathrm{~mm}$ & 828.62 & 284.84 \\
\hline \multicolumn{2}{|c|}{ Chemical Admixture } & 0.00 & 0.00 \\
\hline \multicolumn{2}{|c|}{ Water-Cement ratio } & 0.38 & 0.38 \\
\hline \multicolumn{2}{|c|}{ Slump in $\mathrm{mm}$ after 1 hour of addition of water } & 30 & 28 \\
\hline Mix-A & \multicolumn{3}{|c|}{ Design done on Nominal Aggregates sizes of $20 \mathrm{~mm}$} \\
\hline Mix-B & \multicolumn{3}{|c|}{ Design done on Nominal Aggregates sizes of 40mm } \\
\hline
\end{tabular}

The test specimen for, flexural strength and equivalent cube strength were prepared and tested according to IS: 516-2004. Using the above specified material, concrete of grade M40 being developed. To measure the flexural strength $150 \mathrm{~mm} \times 150 \mathrm{~mm} \times 700 \mathrm{~mm}$ beam for flexural strength. The broken piece of Beam has been used for measuring the Equivalent Cube Strength.

\section{Discussion}

As Concrete Road Flexural failure is predominant for that reason flexural Strength is considered for defining the target mean strength for Mix design Calculation. The transition zone between aggregate and hydrated cement paste (HCP) is the weakest link in the concrete. Due to the presence of high water cementations material ratio in the transition zone compared to other portion of the concrete, it contains large size and numbers of capillary voids as well as micro-cracks created during the manufacture and hardening of concrete. The performance of concrete is adversely affected by the increase in the size and/or number of microcracks in the transition zone. The size and number of micro-cracks are influenced by Aggregate size and grading. A well graded coarse \& fine aggregates mixtures helps to reduces micro-cracks increasing the strength $\&$ durability. 
Mix-A W/C ratio is 0.38 for water content of 186 litres Cement Content Comes out to be $489.47 \mathrm{~kg} / \mathrm{Cum}$. In Mix-B 40mm aggregates are used so water content comes out to be 165 litres instead of 186 litres due to which cement content decrease from 489.47 to $434.21 \mathrm{~kg} / \mathrm{cum}$.

\subsection{To fix the dosage of super plastizer for using it in Design Mix \& Prepare Mix C}

Different brand of admixtures i.e. Super-plasticizer are available in market. In these experiment investigations admixtures for slump retention is used In this experimental program brand like Forsac, Fairmate, Sika \& Lovely Chemicals are used to verify the required dosage to obtained the design slump of $30 \mathrm{~mm}+5 \mathrm{~mm}$, This slump is required @ retention time of 1 hours.

Very first the dosage of admixture was established on trial for $30 \pm 5 \mathrm{~mm}$ slump. Dosage of admixture of $0.5 \%, 1.0 \%, 1.2 \%, 1.5 \%$ and $2.0 \%$ were used. This value was plotted on graph to obtain the optimum dosage required to get $30 \pm 5 \mathrm{~mm}$ slump. Mix $\mathbf{C}$ is Developed with adding $1 \%$ age of admixture of N-170.

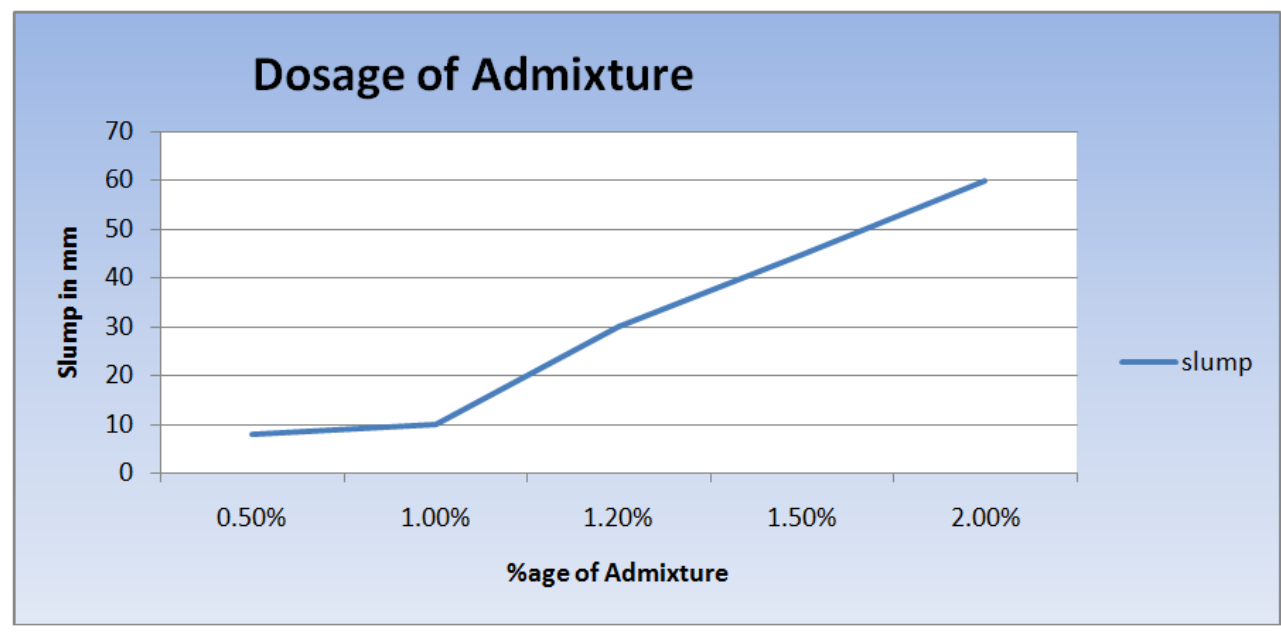

Table 4.2 Design of Mix Proportion for M40 for Designed flexural strength

\begin{tabular}{|c|c|c|c|}
\hline \multicolumn{2}{|l|}{ Ingredients in KG } & Mix-B & Mix-C =Mix B-1.2 \\
\hline \multicolumn{2}{|l|}{ Cement } & 434.21 & 390.79 \\
\hline \multicolumn{4}{|l|}{ Fly Ash } \\
\hline \multicolumn{2}{|l|}{ Water } & 165.00 & 148.50 \\
\hline \multirow[t]{2}{*}{ Fine Aggregate } & Narmada & 243.31 & 250.11 \\
\hline & Tapi & 243.31 & 250.11 \\
\hline \multirow[t]{3}{*}{ Coarse Aggregate } & $40 \mathrm{~mm}$ & 569.67 & 585.58 \\
\hline & $20 \mathrm{~mm}$ & 569.67 & 585.58 \\
\hline & $10 \mathrm{~mm}$ & 284.84 & 292.79 \\
\hline \multicolumn{2}{|l|}{ Chemical Admixture } & 0.00 & 4.69 \\
\hline \multicolumn{2}{|l|}{ Water-Cement ratio } & 0.38 & 0.38 \\
\hline \multicolumn{2}{|c|}{ Slump in mm after 1 hour of addition of water } & 28 & 32 \\
\hline Mix-B & \multicolumn{3}{|c|}{ Design done on Nominal Aggregates sizes of $40 \mathrm{~mm}$} \\
\hline Mix-C =Mix B-1.2 & \multicolumn{3}{|c|}{ Design done on Nominal Aggregates sizes of $40 \mathrm{~mm}$ with different Super Plasticizer Dosage } \\
\hline
\end{tabular}

\section{Discussion}

Out of the three admixtures brand used, Super Plasticizer: Lovely N-170 which is modified Naphthalene Formaldehyde sulphonate type is better \& economical. It is dark brown in colour and specific gravity is around 1.16 to 1.20 . It complies with IS: 9103, ASTMC 494 Type F and BS: 5075 part 3 . The control of water content is most essential which is obtained by adding a super-plasticizing admixture. As Super plasticizer is used water content further reduced to 148.50 litres without changing the workability. The cement content reduces to $390.79 \mathrm{~kg} / \mathrm{cum}$

\subsection{M40 Trial Mix With Chemical as well as Mineral Admixtures Mix D, Mix E, Mix F.}

Three different mixtures are developed for this work out of High-Volume Fly Ash concrete. The experiment of Trial mixes was carried out on three proportion of Fly ash replacement. Each mixture was batched and mixed in mixer machine. Test Specimen was prepared to measure properties of each mixture, in accordance with ASTM C 31. Each Mixture was tested for fresh and hardened concrete properties. 
Table 4.3 Mix Proportion for Trial for M40 with fly-ash for flexure strength

\begin{tabular}{|c|c|c|c|c|}
\hline \multicolumn{2}{|l|}{ Ingredients } & Mix-D & Mix-E & Mix-F \\
\hline \multicolumn{2}{|l|}{ Cement } & 322.40 & 251.31 & 171.95 \\
\hline \multicolumn{2}{|l|}{ Fly Ash } & 107.47 & 167.54 & 210.16 \\
\hline \multicolumn{2}{|l|}{ \%age of Fly Ash } & $25 \%$ & $40 \%$ & $55 \%$ \\
\hline \multicolumn{2}{|l|}{ Water } & 148.50 & 148.50 & 132.00 \\
\hline \multirow[t]{2}{*}{ Fine Aggregate } & Narmada & 342.15 & 337.8 & 350.79 \\
\hline & Tapi & 146.63 & 144.77 & 150.34 \\
\hline \multirow{3}{*}{$\begin{array}{l}\text { Coarse } \\
\text { Aggregate }\end{array}$} & $40 \mathrm{~mm}$ & 572.2 & 564.93 & 586.65 \\
\hline & $20 \mathrm{~mm}$ & 357.62 & 353.08 & 366.66 \\
\hline & $10 \mathrm{~mm}$ & 518.15 & 494.31 & 513.32 \\
\hline \multicolumn{2}{|c|}{ Chemical Admixture } & 5.16 & 5.16 & 4.59 \\
\hline \multicolumn{2}{|c|}{ Water-Cement ratio } & 0.46 & 0.58 & 0.77 \\
\hline \multicolumn{2}{|c|}{$\begin{array}{l}\text { Slump in } \mathrm{mm} \text { after } 1 \text { hour of addition of } \\
\text { water }\end{array}$} & 32 & 30 & 35 \\
\hline Mix-D & \multicolumn{4}{|c|}{ Design done on Nominal Aggregates sizes of $40 \mathrm{~mm}$ with $25 \%$ Fly Ash Replacement } \\
\hline Mix-E & \multicolumn{4}{|c|}{ Design done on Nominal Aggregates sizes of $40 \mathrm{~mm}$ with $40 \%$ Fly Ash Replacement } \\
\hline Mix-F & \multicolumn{4}{|c|}{ Design done on Nominal Aggregates sizes of 40mm with 55\% Fly Ash Replacement } \\
\hline
\end{tabular}

\subsection{Details of Hardened Properties of Test Specimen}

The following table gives the value of Test results carried out in house laboratory

Table No 4.4 Details of Flexure Strength of 150mm X 150mm X 700mm size Beam \& Equivalent Cube Strength of Broken Beam

\begin{tabular}{|c|c|c|c|c|c|c|}
\hline \multirow{2}{*}{$\begin{array}{l}\text { Sr. } \\
\text { No. }\end{array}$} & \multirow{2}{*}{$\begin{array}{l}\text { Mix } \\
\text { Details }\end{array}$} & \multirow{2}{*}{$\begin{array}{l}\text { Density } \\
\text { Kg/Cum }\end{array}$} & \multicolumn{2}{|c|}{ Beam's Flexural Strength } & \multicolumn{2}{|c|}{ Equivalent Cube Strength } \\
\hline & & & $\begin{array}{l}7 \text { days strength in } \\
\mathrm{N} / \mathrm{mm}^{2}\end{array}$ & $\begin{array}{l}28 \text { days strength } \\
\text { in } \mathrm{N} / \mathrm{mm}^{2}\end{array}$ & $\begin{array}{l}7 \text { days Beam strength } \\
\text { in } \mathrm{N} / \mathrm{mm}^{2}\end{array}$ & $\begin{array}{l}28 \text { days Beam } \\
\text { strength in } \mathrm{N} / \mathrm{mm}^{2}\end{array}$ \\
\hline 1 & Mix-A & 2580 & 4.267 & 5.689 & 31.11 & 42.67 \\
\hline 2 & Mix-A & 2519 & 5.333 & 6.4 & 32.89 & 48.89 \\
\hline 3 & Mix-A & 2486 & 4.627 & 5.689 & 28.89 & 53.33 \\
\hline 4 & Mix-B & 2604 & 3.2 & 5.867 & 32 & 42.67 \\
\hline 5 & Mix-B & 2616 & 4.27 & 6.578 & 32.89 & 53.33 \\
\hline 6 & Mix-B & 2604 & 3.91 & 6.044 & 35.56 & 51.11 \\
\hline 7 & Mix-C & 2779 & 4.089 & 6.044 & 32.44 & 44.44 \\
\hline 8 & Mix-C & 2633 & 6.222 & 6.756 & 31.11 & 51.11 \\
\hline 9 & Mix-C & 2673 & 5.511 & 6.222 & 31.56 & 54.22 \\
\hline \multirow{2}{*}{$\begin{array}{l}\text { Sr. } \\
\text { No. }\end{array}$} & \multirow{2}{*}{$\begin{array}{l}\text { Mix } \\
\text { Details }\end{array}$} & \multirow{2}{*}{$\begin{array}{l}\text { Density } \\
\text { Kg/Cum }\end{array}$} & \multicolumn{2}{|c|}{ Beam's Flexural Strength } & \multicolumn{2}{|c|}{ Equivalent Cube Strength } \\
\hline & & & $\begin{array}{l}7 \text { days strength in } \\
\mathrm{N} / \mathrm{mm} 2\end{array}$ & $\begin{array}{l}28 \text { days strength } \\
\text { in } \mathrm{N} / \mathrm{mm} 2\end{array}$ & $\begin{array}{l}7 \text { days Beam strength } \\
\text { in } \mathrm{N} / \mathrm{mm} 2\end{array}$ & $\begin{array}{l}28 \text { days Beam } \\
\text { strength in } \mathrm{N} / \mathrm{mm} 2\end{array}$ \\
\hline 10 & Mix-D & 2575 & 3.90 & 6.044 & 32.13 & 42.67 \\
\hline 11 & Mix-D & 2519 & 4.27 & 6.578 & 32.89 & 48.89 \\
\hline 12 & Mix-D & 2590 & 3.80 & 5.867 & 29.79 & 47.37 \\
\hline 13 & Mix-E & 2580 & 3.85 & 6.044 & 32.89 & 48.77 \\
\hline 14 & Mix-E & 2550 & 3.90 & 6.222 & 31.15 & 52.34 \\
\hline 15 & Mix-E & 2604 & 4.29 & 6.587 & 34.54 & 50.12 \\
\hline 16 & Mix-F & 2525 & 3.55 & 6.400 & 33.45 & 44.44 \\
\hline 17 & Mix-F & 2585 & 3.95 & 6.044 & 32.15 & 49.15 \\
\hline 18 & Mix-F & 2595 & 3.95 & 6.222 & 32.58 & 48.32 \\
\hline
\end{tabular}

Discussion: The Flexural strength test data are given in Table 4.4 As expected, the Flexural strength increased with age. The rate of increase depended upon the level of cement replacement, type of fly ash, and age. In general concrete strength decreased with increasing fly ash concentration at th For Mix-A with 20mm Nominal aggregates, with no admixture cement content is $489.47 \mathrm{~kg}$ keeping same W/C ratio of 0.38 the Target Flexural strength of $5 \mathrm{MPa}$ is achieved with required slump of $30 \mathrm{~mm}$. The equivalent Cube Strength obtained is 48.29 $\mathrm{N} / \mathrm{mm} 2$. From Mix A to Mix F the Cement Content is decreased first by replacing maximum aggregate from $20 \mathrm{~mm}$ to $40 \mathrm{~mm}$ then by adding Chemical and Mineral Admixture. The Cement content of Mix F with 40mm Nominal aggregates, with $1.2 \%$ admixture, cement content is $171.95 \mathrm{~kg} \&$ Fly ash $210.16 \mathrm{Kg}$ (55\%age replacement) with same W/C ratio of 0.38 the 28 Day's Flexural Strength is $6.222 \mathrm{~N} / \mathrm{mm} 2$ \& Equivalent Cube strength is $47.30 \mathrm{~N} / \mathrm{mm} 2$ against required e very early ages.

Flexural strength of $4.91 \mathrm{~N} / \mathrm{mm} 2$ with achieved slump of $35 \mathrm{~mm}$.

\subsection{Preparation of High Performance Concrete for Pavement Quality Concrete (PQC) to be used in} Highway Pavements.

M40 Concrete is prepared on Basis of IRC: 44-2008, Design Guide lines as provided in IRC: 15-2011 "Standard Specification and code of practice for construction of Concrete Roads" is followed Gradation of aggregates as provided in table: 3 of IRC: 15 is followed. Super plasticizer can be added up-to $2 \%$, but here 
$1.2 \%$ age is added. After preparing the final Mix fiber dosage at the rate of $125 \mathrm{gm}$ per $50 \mathrm{~kg}$ of Cementious Material is used. A Trial Patch of @ $1.0 \mathrm{mt}$ X $3.0 \mathrm{mt}$ of $300 \mathrm{~mm}$ thickness done, its site evaluation of strength is done by cutting 3 nos of cores and working out is compressive strength.

\subsection{Mix Proportion for Trial for M40 with fly-ash for flexure strength}

\begin{tabular}{|c|c|c|c|}
\hline \multicolumn{2}{|l|}{ Ingredients in KG } & Trial-1 & For Beam set 1 \\
\hline \multicolumn{2}{|l|}{ Cement } & 171.95 & 30.467 \\
\hline \multicolumn{2}{|l|}{ Fly Ash } & 210.16 & 37.237 \\
\hline \multicolumn{2}{|l|}{ Water } & 132.00 & 23.389 \\
\hline \multirow[t]{2}{*}{ Fine Aggregate } & Narmada & 349.39 & 61.908 \\
\hline & Tapi & 149.74 & 26.532 \\
\hline \multirow[t]{3}{*}{ Coarse Aggregate } & $40 \mathrm{~mm}$ & 584.31 & 103.533 \\
\hline & $20 \mathrm{~mm}$ & 365.20 & 64.708 \\
\hline & $10 \mathrm{~mm}$ & 518.15 & 91.809 \\
\hline \multicolumn{2}{|l|}{ Chemical Admixture } & 4.59 & 0.812 \\
\hline \multicolumn{2}{|c|}{ Water-Cement ratio } & 0.77 & 0.77 \\
\hline \multicolumn{2}{|c|}{ Slump in $\mathrm{mm}$ after 1 hour of addition of water } & 38.00 & \\
\hline
\end{tabular}

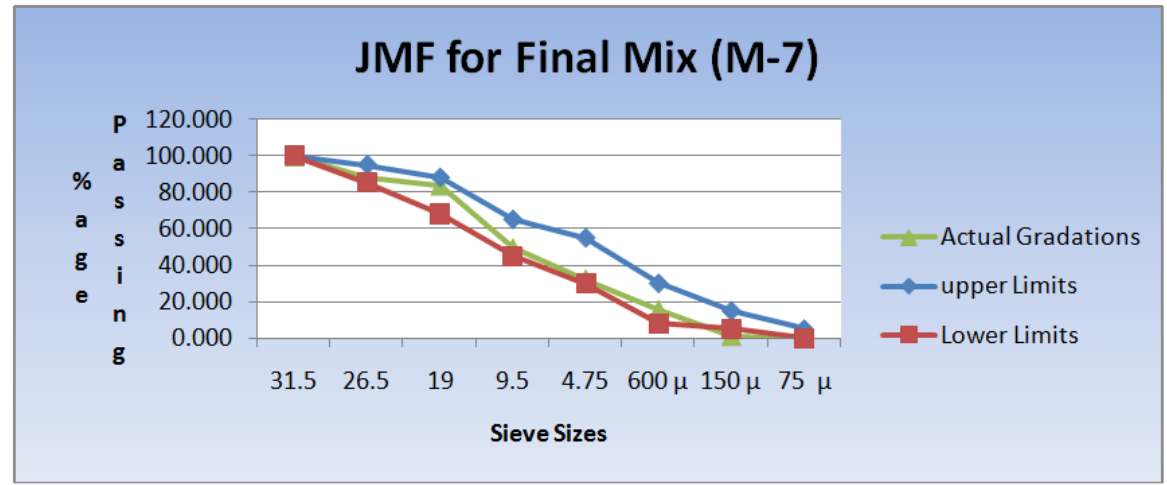

\section{Summary \& Conclusion}

Conclusion from Experimental study of Old \& New code used for Concrete Mix Design, \& Deciding Admixture Type \& Dosage quantity. As per table 3.1 all four mixes can be used, but the Mix with Highest aggregates cement ratio must be used which will be more economical.

The $30 \mathrm{~mm} \pm 5 \mathrm{~mm}$ slump is worked out for One hour retention time, Out of the three admixtures brand used, Super Plasticizer: Lovely N-170 which is modified Naphthalene Formaldehyde sulphonate type is better \& economical. The dosage of admixture is fixed at $1.2 \%$ by weight of Cementitious material used.

Conclusion from Trial Mix of Mix-A, Mix-B, Mix-C, Mix-D, Mix-E, Mix-F

Mix-A is having Cement content of $489 \mathrm{~kg}$ were as Mix F is having Cement content of $172 \mathrm{Kg}$. The indirect saving in Carbon Emission of Mix-F is greatest out of all the six Design mixes. For Mix-F with $40 \mathrm{~mm}$ nominal Aggregates and with 55 \%age Cement replacement by Fly ash the 28's Day Flexural Strength is $6.222 \mathrm{~N} / \mathrm{mm}^{2}$ against requirement of $4.91 \mathrm{~N} / \mathrm{mm}^{2}$, The equivalent cube strength comes out to be $47.303 \mathrm{~N} / \mathrm{mm}^{2}$ with slump achieved of $35 \mathrm{~mm}$ after one hour retention time.

Conclusion from Trial Mix of Mix-7 and Results from trial patch.

The trail mix can be readily used for in field placement of concrete road pavement work for constructing the trail length. As per MORTH the trial length shall be constructed at least one month in advance of the proposed start of concrete paving work. Ingredient of Mix-7 can be readily used for laying. The demonstration for material, for plant, equipment and method of construction that are proposed for concrete.

As per Guidelines of IRC:SP:84-2014 any alternative material, technology/method, that is not covered in the Indian or International standards but the use of which has been permitted on similar projects, as the project Highway such as NH-4 from Satara - kolhapur, Kagal section completed in the year 2005, its continued successful performance of materials for at-least 5 years which is a supportive for its critical performance can be a very good support for design of sustainable green Pavement concrete.

\section{References}

[1]. IRC:15-2011 Standard Specification and code of practice for construction of Concrete Roads

[2]. IRC:44-2008 Guidelines for Cement Concrete Mix Design for Pavements

[3]. IRC:58-2008 Guidelines for the Design of Plain Jointed Rigid Jointed Rigid Pavements for Highways

[4]. IS: 1226953 Grade ordinary Portland cement

[5]. IS: 1489 (Part 1) Portland Pozzolana cement (fly ash based)

[6]. IS: 26933 Grade ordinary Portland cement 
[7]. IS: 455 Portland slag cement

[8]. IS: 516-1963 Indian Standard Methods of Test for Strength of Concrete

[9]. IS: 811243 Grade ordinary Portland cement

[10]. IS:10262-2009 Indian Standard Concrete Mix Proportioning-Guidelines

[11]. IS:2386-1963 Methods of Test for Aggregates for Concrete

[12]. Part: I Particle Size \& Shape.

[13]. Part: II Estimation of Deleterious Materials and Organic Impurities.

[14]. Part: III Specific Gravity, Density, Voids, Absorption and Bulking

[15]. Part: IV Mechanical Properties

[16]. IS:383-1970 Specification for Coarse and Fine Aggregates from Natural Sources for Concrete

[17]. IS:456-2000 Plain and Reinforced Concrete-Code of Practice

[18]. IS:516-1963 Methods of Tests for Strength of Concrete

[19]. Shibashish P Mukherjee, Dr. Gaurang Vesmawala Exploring Fly Ash Utilization in Construction of Highway in India, ISOR-JMCE Oct-2013

[20]. M.S. Sheety Concrete Technology

[21]. Neville Properties of Concrete

[22]. SP: 23-1982 Handbook on Concrete Mixes Based on Indian Standard

[23]. Construction Technology by Karan Communications.

[24]. Specifications for Roads \& Bridges works (fourth revision)

[25]. Khanana \& Justo Highway Engineering

[26]. Sanjay Srivastava's Laboratory Investigation of High Performance Concrete for High Pavements.

[27]. P Kumar Mehta's High-Performance, High-Volume Fly Ash Concrete for Sustainable Development

[28]. Tarun R Naik's Performance of High-Volume Fly Ash Concrete Pavements since 1984

[29]. Concrete Sustainability Report National Ready Mixed Concrete Association MIT

[30]. Research: Life Cycle Assessment of Concrete Pavements

[31]. Karthik H Obla "What is Green Concrete 2009", The Indian Concrete Journal April 2009.

[32]. INDIAN ROADS CONGRESS Highway Research Records

[33]. Dhirendra Singhal ${ }^{1}$, Sanjiv Kumar Aggarwal ${ }^{2}$, Jaspreet Singh Brar $^{2}$ CONCRETE MIX DESIGN IS: 10262-

2009 Vs IS:

10262 - 1982 UKIERI Concrete Congress Innovations in Concrete Construction 